\title{
Concepções filosóficas do nacionalismo teuto-brasileiro do século XIX
}

Paulo Gilberto Mossmann Sobrinho ${ }^{1}$

\section{Resumo}

Busca-se apresentar neste artigo como os teuto-brasileiros, outrora identificados como "apolíticos", afirmaram uma nova identidade político-social, a partir das atividades de intelectuais de origem alemã. Estes, através da busca da construção identitária nacionalista, possibilitaram a inserção social desse povo europeu, com características tão díspares em relação à sociedade brasileira gestada por portugueses, indígenas e africanos, desde o início do século XV. Ao indicar-se que a construção identitária nacionalista foi de fundamental importância para o engajamento dos alemães e seus descendentes na sociedade brasileira, traz-se como pano de fundo uma questão de vasta relevância: como o nacionalismo alemão influenciou esses intelectuais que constituíram a concepção da importância dos teutos-brasileiros, especialmente no Rio Grande do Sul, durante o século XIX?

Palavras-chave: Nacionalismo. Identidade. Germanismo. Teuto-brasileiro.

\begin{abstract}
To discuss this article as the Teutons-Brazilians, once identified as "apolitical", eventually establish a new political and social identity from the intellectual activities of German origin. These, hat through the pursuit of nationalist identity construction, enabled the engagement of these people European with such different characteristics in relation to Brazilian society gestated by Portuguese, Indians and Africans since the start of the fifteenth century. To be stated that the nationalist identity construction was essential to engage the Germans and their descendants in Brazilian society, has as its background a matter of vast importance: How German nationalism influenced these intellectuals who formed the conception of importance of the Teutons, especially Brazilians in Rio Grande do sul during the century. XIX?
\end{abstract}

Keywords: Nationalism. Identity. Germanism. German-Brazilian.

\footnotetext{
${ }^{1}$ Graduado em História pelas Faculdades Integradas de Taquara - Faccat/RS. Mestrando em História.sobrinho.historia@gmail.com
} 


\section{Introdução}

No ano de 1824, iniciou, no Rio Grande do Sul, o processo de imigração alemã. Considera-se a vinda desses imigrantes um marco na história do Rio Grande do Sul. Esse processo imigratório propiciou, a partir da metade do século XIX e idos do século XX, uma divisão do estado sul-rio-grandense em duas grandes regiões: região norte e região sul. A norte, tendo especialmente a imigração teuto-italiana, passou a apresentar uma maior dinâmica e diversificação em sua economia em contrapartida à região sul, que era formada por grandes estâncias, cuja economia de cunho basicamente pecuária, estava por iniciar um processo de estagnação econômica.

A vinda desses imigrantes alemães pode ser compreendida a partir de uma expectativa de que na América houvesse a possibilidade de ascensão social muito mais rápida do que na Europa, devido a sua estrutura social ser menos rígida do que a europeia (DREHER, 1995) ${ }^{2}$. Com essas premissas, ficou evidenciada, no decorrer do século XIX, a influência dos alemães na composição da sociedade sul-rio-grandense.

Ao retratar a presença, a participação dos germânicos, ou dos também conhecidos como Deutsch-Brasilianer, na sociedade sul-rio-grandense, muito se produziu, em diversos eventos, seminários, academicamente falando, sobre a importância dessa etnia na constituição de aspectos culturais (folclóricos - com aspectos extravagantes ou exagerados), aspectos de valorização no desenvolvimento econômico - tanto num sentido de desbravar as matas que urbanizaram, quanto naquele que ajudou no processo de industrialização do Rio Grande do Sul. Inclusive, ocorre uma perigosa construção historiográfica, que apresenta uma imagem extremamente positiva do teuto-brasileiro, atribuindo-lhe muitas virtudes e poucos, ou até mesmo nenhum ato invirtuoso. Além de estabelecer, ainda, uma insolente imagem homogênea, como se o cotidiano, o comportamento de todos os colonos alemães das diversas colônias existentes no Rio Grande do Sul, tivessem a mesma conduta. No que tange à participação dos teuto-brasileiros nas questões políticas, atribui-se uma imagem de indivíduos apolíticos ${ }^{3}$.

A partir dessa premissa, pretende-se abordar, neste artigo, como esses teuto-brasileiros, outrora identificados como "apolíticos", acabaram por firmar uma nova identi-

\footnotetext{
${ }^{2}$ Destaca-se que entre os fatores determinantes para que estes imigrantes alemães atravessassem o Atlântico não estava somente o aspecto financeiro, a condição de miserabilidade e desprestígio social que motivaram o seu deslocamento para o Rio Grande do Sul. Os imigrantes buscavam construir uma nova vida, uma nova sociedade, inclusive Dreher (1995) nos apresenta o simbolismo do Éden nesta "nova" terra selvagem, onde o homem está em harmonia com Deus. Evidentemente que o "Éden" não era o mesmo paraíso prometido ou sonhado. Não se chegou a entrar na discussão das promessas cumpridas, pois o autor julgou não ser o foco deste trabalho. Contudo, há de se relatar as dificuldades de estabelecimento para estes imigrantes alemães. Isso, com certeza, justifica a ideia do associativismo que foi tão forte entre os alemães. Era necessária a união para combater as dificuldades, quer fossem elas financeiras, por saudades da terra mãe, ou até mesmo pela dificuldade em se estabelecer num país tão diferente em língua e costume.

3 "Várias são as tentativas, na historiografia, de dar inteligibilidade a indícios de participação política, além da representação política tradicional, no intuito de desvendar o processo de construção da cidadania entre os teuto-brasileiros, seja na prática ou no campo do discurso. Essas novas leituras sobre a colonização alemã atentam para o envolvimento político dos teutobrasileiros, ao contrário de estudos orientados por um viés fundado na ideia de vitimização dos colonos/imigrantes diante do que seria uma 'legislação excludente' e no conceito de isolamento" (OLIVEIRA, 2008, p. 80).
} 
dade político-social, a partir das atividades de intelectuais de origem alemã, os quais, através da busca da construção identitária nacionalista, possibilitaram o engajamento desse povo europeu às características tão díspares em relação à sociedade brasileira, gestada por portugueses, indígenas e africanos desde os idos do século XV.

Ao referir que a construção identitária nacionalista foi de fundamental importância para o engajamento dos alemães e seus descendentes na sociedade brasileira, traz-se como pano de fundo uma questão de vasta relevância: Como o nacionalismo alemão influenciou a esses intelectuais que constituíram a concepção da importância dos teuto-brasileiros, especialmente no Rio Grande do Sul, durante o século XIX?

\section{0 nacionalismo alemão}

Para compreender aspectos relevantes do nacionalismo alemão, buscou-se uma resposta na análise da obra de dois filósofos alemães: Johann Gottfried von Herder e Johann Gottlieb Fichte, do final do século XVIII e início do século XIX, que serviram de base para o nacionalismo alemão no decorrer do século XIX.

Johann Gottfried von Herder ${ }^{4}$

Johann Gottfried von Herder destacou-se como precursor do Romantismo, que misturou o sentimento nacionalista alemão com o desejo de conhecimento universal, próprio do século XVIII. Dentre as principais ideias defendidas por Herder, que permearam as concepções do nacionalismo teuto-brasileiro do século XIX, destacam-se as ligadas à língua, à conduta humana e à valorização das tradições.

O principal instrumento intelectual é a língua, sendo a linguagem um presente de Deus, a qual diferencia os homens dos animais. A linguagem também promove e diferencia as culturas humanas - superiores e inferiores. A capacidade de observar os signos representa a complexidade das linguagens e a arte se originou da união do prazer com a observação e a transformação dos signos.

A conduta humana é outra questão central na obra de Herder (1959). Na sua concepção, o homem é uma máquina que precisa ser ensinada, por isso, a valorização da educação tecnicista. Contudo, sem deixar de lado aspectos religiosos, pois em seus preceitos a religião em terra de selvagens leva ao povo a evolução científica e cultural. Dessa maneira, o homem é visto como um ser social e necessita estabelecer uma conduta social harmônica - há valorização da educação moral, em que o mais astuto pode superar o mais forte.

Outro aspecto salientado por Herder (1959) é a valorização da tradição, que é de fundamental importância para a sociedade, pois ela serve como instrumento de ensino ao povo, o seu modo de agir e compreender a mentalidade.

Nesses ensinamentos, se estabelece como base a valorização da história do povo, representada através dos antepassados. Desse modo, fica em destaque o caráter nacional que está impregnado num povo, assim como o caráter natural, que originam a

\footnotetext{
${ }^{4}$ Obra de referência consultada para o artigo: HERDER, Johann Gottfried Von. Ideas para una filosofía de la historia de la humanidad. Buenos Aires: Editorial Losada, 1959.
} 
máxima nacionalista: $A$ mãe nação não abandona seus filhos.

Johann Gottlieb Fichte ${ }^{5}$

Johann Gottlieb Fichte é considerado um dos principais filósofos idealistas e de maior destaque na Alemanha, nos primeiros vinte e cinco anos do século XIX. Procurou, em seus trabalhos, em atitude oposta a Herder, discutir não o aspecto universal em suas concepções, e sim os pontos que diferenciavam os alemães dos demais povos.

Para Fichte (2010), a valorização do povo alemão possui características únicas, apesar de ser mais um entre outros tantos povos de origens germânicas, pois os alemães mantiveram a língua vernácula e, por conseguinte, mantiveram a cultura original. Os demais povos germânicos migraram por grande parte da Europa (especialmente o norte) e parte da Ásia. Assim, além de perderem o vínculo com a terra natal, perderam, por consequência, sua cultura, já que se aculturaram, deixaram de serem dominantes e passaram a dominados.

Contudo, Fichte (2010) admite a influência de línguas estrangeiras no alemão, mas que os termos estrangeiros não interferiram na essência dessa linguagem. Além disso, afirma que a língua representa um fator significativo para o estabelecimento e autonomia de uma nação, sendo de grande valia para a elaboração de leis e normas (o entendimento social). Somente com a língua vernácula é possível manter as origens do povo, a cultura e, essencialmente, suas virtudes - caracterizando, assim, um povo com sentimentos coletivos, em que não há segregação entre cultos e incultos, algo diferente em relação aos demais germânicos, que fazem uma separação entre os cultos, que manipulam, e o povo, que é manipulado. E ainda, ele afirmava que o povo é a causa e razão de toda nação, evidenciando as virtudes natas do povo alemão, como fidelidade, sinceridade, honra e simplicidade.

Fichte e sua obra estão inseridos, historicamente, num contexto de invasões napoleônicas e a grande preocupação do referido filósofo estava em alertar ao povo alemão sobre a importância da preservação de sua língua como elemento fundamental para preservação do caráter nacionalista em uma sociedade que não estava constituída como pátria unificada até aquele momento ${ }^{6}$. Desse modo, são constantes as críticas às tentativas de domínios estrangeiros. Estrangeiros seriam "ignorantes", de "mau gosto" e "má educação". E em contrapartida, os alemães se caracterizavam como homens das nações cultas e superiores, que não têm a obrigação de ajudar às nações incultas.

A educação seria outro fator nevrálgico para o fortalecimento da nação - a fé deveria ser instrutiva em todos os segmentos - remetendo à influência da escolástica na doutrina de Lutero - que seria outro fator que diferenciava o povo alemão dos demais, justamente por possuírem uma religião mais adequada à nova realidade da época.

As demais religiões (especialmente a católica) estavam corroídas estruturalmente e moralmente.

${ }^{5}$ Obra de referência consultada para o artigo: FICHTE, Johann Gottlieb. Discursos à nação alemã. Circulo de Leitores - Temas e Debates, Lisboa/Portugal, 2010.

${ }^{6} \mathrm{~A}$ unificação dos 39 reinos de origem alemã como uma única pátria só ocorreu o ano de 1871 . 


\section{As origens do pensamento teuto-brasileiro}

A partir da breve apresentação das selecionadas ${ }^{7}$ ideias de Herder e Fichte, almeja-se compreender a formação do pensamento nacionalista teuto-brasileiro. Constatase que tal pensamento foi fruto de um movimento intelectual conhecido como germanismo:

O germanismo é um movimento intelectual surgido entre meados do século XIX e a década de 1940 entre indivíduos do grupo étnico alemão no Brasil, tendo como preocupação central a defesa da identidade étnico-nacional da população imigrante. Foi encabeçado por figuras da elite teuta - jornalistas, professores, pastores, comerciantes, industriais - que forjaram uma identidade específica para esta população com base na distinção étnica - propriamente etnocêntrica - em que são tomadas características culturais e biológicas como elementos diferenciadores. Como o próprio nome revela, o germanismo não é apenas um movimento de valorização de um caráter, identidade ou modo de ser alemão, mas também tem suas origens numa concepção de unidade cultural germânica própria ao nacionalismo do século XIX (SILVA, 2005, p. 311).

Encontram-se impregnados na concepção do germanismo vários elementos de influências do pensamento de Herder e Fichte. Essas características evidenciam-se através de alguns preceitos.

Pode-se citar, por exemplo, o Romantismo alemão ${ }^{8}$, tendo Herder como seu grande expoente. Acreditava-se na valoração do "heróico" passado alemão, além do papel fundamental que o idioma alemão representava para a preservação da memória/identitária do povo, tendo na questão da preservação do idioma um dos pontos-chave tanto para Herder como para Fichte.

Ainda se pode referir a reação ao domínio francês, iniciado na Europa com as conquistas napoleônicas. Esse domínio francês está, no caso do Brasil, muito relacionado com o "modo de ser francês", como padrão de elegância e de comportamento na sociedade. Inclusive, o jornalista e político alemão Karl Von Koseritz (o qual se evidenciará mais adiante nesse artigo) criticou muito, em sua viagem ao Rio de Janeiro, no final do século XIX, a postura afrancesada da população (GRÜZTZMANN, 2007).

Pode-se destacar, ainda, a "superioridade das raças", evolucionismo e anti-semitismo (momento posterior). A partir dessa ideia, o alemão foi considerado, ou considerou-se, um ser superior ao povo brasileiro ${ }^{9}$, por ser mais capacitado para atividades

\footnotetext{
${ }^{7}$ Destaca-se que foram selecionadas somente ideias que, de acordo com a ótica do autor do artigo, estavam mais evidenciadas no incipiente nacionalismo alemão que influiu na formação do nacionalismo teuto-brasileiro, sendo as obras de Herder e Fichte de uma abrangência bem mais complexa, destacando, sobretudo estudos da filosofia e da semântica, do que os poucos pontos levantados.

${ }^{8}$ As ideias que compõem o germanismo advêm, de um modo geral, do romantismo alemão, que serviu de alicerce para a formação de um sentimento nacional, um desejo de unidade como nação, a base do nacionalismo alemão do século XIX. Os românticos buscaram na língua o elo de ligação do povo germânico, traço comum aos indivíduos da nação alemã, uma ideia de nação cultural que não previa a unificação política (SILVA, 2005).

${ }^{9} \mathrm{O}$ pioneirismo dos colonos, a eficiência do colonizador teuto são contrapostos a uma imagem estereotipada do brasileiro rural, desqualificado como caboclo por todo um conjunto de características desabonadoras, remetidas a uma condição de inferioridade racial (SEYFERTH, 1993).
} 
econômicas mais complexas e apresentar uma cultura mais elaborada. Apesar de contrariar Fichte, que dizia que não existia obrigação da cultura superior ajudar a inferior, os germanistas pregavam que a função dos alemães, no Brasil, seria "humanitária", ajudando o jovem país americano a se desenvolver economicamente.

Deve-se referir, também, a ideia de separação de "Nação" e "Pátria". Essa é uma questão nevrálgica para o nacionalismo teuto-brasileiro. Baseados principalmente na concepção de Fichte, segundo a qual a questão étnica é fundamental para a formação da nação, e não necessariamente a questão da formação de uma pátria, os germanistas estabeleceram a concepção de que a nova pátria seria o Brasil (questão político-territorial), mas a nação continuaria a ser a alemã, pois bastava aos descendentes seguirem o "Volkstum, entendido como a essência do povo, o caráter, também etnicidade (tomada como identidade primordial de um grupo), e Deutschtum (germanidade) como a essência do povo alemão" (SILVA, 2005, p. 299, grifo nosso).

A partir da ideia da preservação do Volkstum e do Deutschtum, concebeu-se o âmago do nacionalismo teuto-brasileiro, segundo o qual:

A nova pátria é a colônia, a nova cidadania a brasileira, mas a etnia continua sendo alemã; o ato de emigrar significou o rompimento com o país de origem, mas não com o Volk (povo/etnia) alemão. O pertencimento sugerido por tal categoria remete, por um lado, a uma entidade supraterritorial - a nação alemã, concebida como entidade cultural e lingüística que une um povo de mesma origem - e, por outro lado, à cidadania e a um território considerado como Heimat ou Vaterland - o Estado brasileiro (SEYFERTH, 1993, sem paginação, grifo nosso).

Nessa amálgama de cidadania (relacionada à pátria) e etnia (ligada à nação), formatou-se as bases do perfil do teuto-brasileiro, chamado de Deutsch-Brasilianer. Sendo os alemães e seus descendentes sendo uma nação pertencente a uma pátria (que englobava outras nações), era necessário que essa nação alemã tivesse direitos políticos nessa pátria. Essas lutas foram intensificadas pela excludência política de grande parte dos teuto-brasileiros, por não terem direito à participação política por não possuírem de fato a cidadania brasileira.

Sendo assim, evidencia-se, inicialmente, a participação dos alemães nas questões políticas não pelo viés político-partidário, e sim pelo da participação política através da conquista do direito de cidadania. Cidadania essa que teve seus horizontes ampliados a partir do artigo número $\mathrm{V}$, do Decreto oㅜ 3.029, de 9 de janeiro de 1881, também alcunhada de Lei Saraiva, que possibilitou a participação dos alemães acatólicos nos meios político-partidários ${ }^{10}$. Esse decreto possibilitou a luta pela cidadania plena, ou seja, pelo direito de participação política, não só por meio do voto, mas também pela possibilidade de ser eleito.

${ }^{10}$ Numa tentativa de ampliar sua atuação política, o líder Gaspar Silveira Martins, senador do império, bateu-se pela concessão do direito de voto aos acatólicos e estrangeiros naturalizados, o que se concretizou com a aprovação da lei Saraiva, em 1881. Através desta lei, os pecuaristas liberais estabeleceram uma aliança política com a ala mais representativa da comunidade alemã colonial: os comerciantes e a elite intelectualizada, que forneceram deputados que realizaram a mediação entre o mundo colonial e a política dos senhores rurais. Em troca de favores à sociedade colonial, arregimentavam-se votos para os liberais (PESAVENTO, 1997, p. 53). 
Com esse novo decreto, Gaspar Silveira Martins conseguiu a cooptação de muitos teuto-brasileiros ao Partido Liberal. Contudo, Dreher (2001) aponta que, mesmo com uma presença significativa dos teuto-brasileiros no Partido Liberal, três grupos político-filosóficos foram engendrados entre os germanistas: os liberais - liderados por Karl von Koseritz; os luteranos - com evidente liderança dos pastores Wilhelm Rotermund e Hermann Dohms; e os católicos - sacerdotes jesuítas que assumem o papel de mentores do grupo alemão, com maior destaque para Theodor Amstad e Max Von Lassberg - com grande influência entre os colonos do interior.

A partir dessas três diferenciações, determinou-se a tendência para a participação político-partidária desses grupos, consubstanciando principalmente os liberais, que tiveram a tendência de participar do Partido Liberal e, posteriormente, Federalista; os luteranos tenderam ao Partido Colonial, e os católicos, ao Partido Católico (GERTZ, 2010).

Salienta-se, inclusive, um forte processo de rivalidade entre esses grupos, destacando-se a intensa briga nos jornais protagonizada pelo pastor Rotermund, que propunha uma atrelagem entre igreja luterana e germanidade como algo intrínseco aos dois elementos - essa amálgama, fé luterana e tradição alemã, já estava expressa em Fichte, que via na religião luterana uma idiossincrasia que diferenciava os povos alemães dos demais. Para Rotermund, os membros da comunidade religiosa luterana que negassem sua germanidade estariam perdidos para a Igreja. Esse aspecto de atrelamento da igreja alemã (luterana) como requisito para a germanidade, ou o Deutschtum, era uma velada crítica ao principal articulador do teuto-brasileirismo, Karl Von Koseritz, que era considerado ateu, apesar de sua ligação com a maçonaria.

Koseritz inclusive merece um enfoque especial nessa análise, pois ele foi considerado o pai do nacionalismo teuto-brasileiro, sua atuação é de relevância tão destacada a ponto de se atribuir a "era Koseritz"11 no processo de consolidação da imagem do teuto-brasileiro.

\section{Karl Von Koseritz}

Karl Julius Christian Von Koseritz nasceu em 3 de fevereiro de 1830, em Dessau. Veio para o Brasil no ano de 1851, com os Brummers (tropas de alemães mercenários contratados para combater na guerra contra Rosas). Assim como muitos outros Brummers, desertou um ano após a chegada ao Brasil, fixando-se junto à cidade de Pelotas, local onde sua tropa estava estabelecida. Numa precária situação, Koseritz acabou trabalhando como cozinheiro e jornaleiro, até que, por volta de 1855, começou a trabalhar como professor, nas cidades de Pelotas e Rio Grande. Em 1858, iniciou sua carreira de jornalista no Brasil, trabalhando junto ao jornal "O Brado do Sul", no ano de 1858.

Apesar de um relativo destaque na região sul do estado do Rio Grande do Sul, Kose-

\footnotetext{
${ }^{11}$ Ainda no que tange à história das ideias, Koseritz é considerado pela historiografia como um dos primeiros intelectuais de origem alemã que problematizou e construiu uma identidade étnico-nacional alemã para os imigrantes e seus descendentes no Brasil, por meio da imprensa, e refletiu acerca da posição deste grupo no contexto brasileiro. A historiografia atribui também a Koseritz a iniciativa pioneira de lutar pelos direitos civis dos imigrantes alemães e de seus descendentes no Brasil (GRÜTZMANN, 2007).
} 
ritz alcançaria maior relevância ante a sociedade sul-rio-grandense ao mudar-se para Porto Alegre, no ano de 1864, onde editou vários jornais e periódicos e recebeu a alcunha de "porta-voz" dos imigrantes germânicos radicados no estado ${ }^{12}$.

Com uma visível ascensão social, Koseritz passa a ter seu reconhecido papel de intelectual, sendo um dos membros da seleta agremiação do Partenon Literário ${ }^{13}$. Entretanto, é no campo da política que este artigo busca enfocar com maior evidência a atuação de Koseritz. A sua atuação está atrelada ao Partido Liberal, que, sob forte influência do líder Gaspar Silveira Martins, conseguiu a aprovação da lei que possibilitou aos imigrantes germânicos a participação política.

Koseritz acreditava que os teutos no Brasil estavam incumbidos da missão histórico-cultural de disseminar a cultura alemã no país, naturalmente para ele superior. Este posicionamento político que visava, ainda que pela perspectiva de cima, a integração dos teuto-brasileiros com o resto do país não era um consenso entre seus membros, sobretudo nas duas últimas décadas do século com a política pangermanista exercida pelo Estado alemão. Koseritz, por sua vez, defendia que a cultura alemã seria propagada pelo país com maior eficiência através do estabelecimento de rincões culturais, que possibilitassem a manutenção de uma identidade cultural homogênea capaz de, só assim, trazer frutos para o país (ARAUJO, 2012, p. 75).

Com a possibilidade de inserção na vida política, Koseritz se candidata a uma cadeira na Assembleia Provincial, no ano de 1883, sendo eleito com a maioria dos votos. Destaca-se que a participação dos imigrantes teutos nestas eleições propiciou a Koseritz a sua eleição. Após ser eleito, foi residir no Rio de Janeiro, sendo recebido pelo Imperador Dom Pedro II. Lá descreveu sua viagem para a capital do Império, Rio de Janeiro, e constatou uma fundamental diferença entre o alemão residente no Rio Grande do Sul e o alemão residente na capital do Império:

Para Koseritz, os alemães estabelecidos no Rio de Janeiro eram apenas simples estrangeiros, por conseguinte, aqueles estabelecidos no sul do país eram estrangeiros diferenciados, que pretendiam se integrar na sociedade brasileira. Ainda que não do ponto de vista cultural, uma vez que Koseritz era fiel defensor da superioridade germânica, mas sim, do ponto de vista político, se defendia a plena participação nos negócios políticos do Brasil, como legítimos cidadãos (ARAUJO, 2012, p. 81).

$\overline{12}$ Karl von Koseritz foi o primeiro que compreendeu a situação peculiar do elemento alemão imigrado no sul do Brasil e pode, por isso, ser denominado o pai do teuto-brasileirismo. Isso significa, em termos negativos, uma delimitação em relação aos alemães do Império Alemão, também em relação a outros brasileiros; em termos positivos significa a aceitação do estado a nova pátria brasileira, bem como o reconhecimento da velha pátria alemã, com a qual o teutobrasileiro continua a sentir-se ligado pela etnia (GERTZ, 1999, p. 7).

${ }^{13}$ Quando se refere à agremiação do Partenon Literário, está se referindo à história do primeiro movimento de intelectuais que de fato estabeleceram uma agremiação no estado do Rio Grande do Sul. Fundada em 18 de junho de 1868, o Partenon Literário era um movimento de ideias, sendo essas as mais diversas e abrangentes possíveis na época. Essas ideias iam de concepções literárias até discussões de aspectos políticos e sociais. O idealismo estabelecido pelos membros do Partenon Literário iniciou, ou incitou, ainda mais no Rio Grande do Sul o questionamento e defesa da concretização de uma nova ordem social, onde temas como a República, abolição da escravidão, o direito a manifestação feminina - além do estabelecimento de aulas noturnas para aqueles que não tinham condições de estudar durante o dia - eram defendidos através de artigos, saraus ou poesias. 
Assim, pode se dizer que, de acordo com as ideias de Koseritz (ARAUJO, 2012), os alemães estabelecidos no Rio Grande do Sul eram mais engajados, faziam parte da sociedade gaúcha/brasileira. Em contrapartida, os que estavam no Rio de Janeiro eram "simplesmente" estrangeiros, porque não estavam integrados na sociedade brasileira.

Koseritz veio a falecer no ano de 1890 (GERTZ, 1999), ao que tudo indica, vitimado por um processo de perseguição política intensa, que passou a sofrer após o advento da república no Brasil, em 1889.

\section{Os jornais como meios de cooptação}

O jornal foi um aporte para a luta pelo poder ${ }^{14}$, através de aspectos simbólicos engendrados, tanto pelos liberais/federalistas - especialmente a partir do jornal $A R e-$ forma - quanto pelos republicanos (com destaque para o jornal A Federação), na busca de justificar suas reivindicações e alcançar uma abrangência maior perante a sociedade. O jornalismo expresso era, essencialmente, de teor partidário e opinativo, não apresentando muito espaço para questões informativas. Através de ásperos editoriais, visava-se a cooptar adeptos partidários. Conforme Rüdiger (2003, p. 36), "O fortalecimento da vida partidária permitiu aos políticos transformar o jornalismo numa militância objetiva, que se tornava meio de formação doutrinária da opinião pública".

Contudo, segundo retratam Hohlfeldt e Rausch (2006), apesar do apelo político-partidário, os diversos jornais existentes no Rio Grande do Sul15 acabavam por um processo de cooptação de leitores; ou, no caso da imprensa partidária, conforme já se referiu em Bourdieu (1998), pela busca por novos clientes:

O que se observa, portanto, é um deslocamento de acentuação, do emissor - um determinado tipógrafo resolve editar um jornal; ou um determinado partido político - para o receptor: mesmo os jornais partidários devem atender a determinadas demandas de seu público, além de divulgarem seus princípios ideológicos. Os jornais vinculados às novas comunidades étnicas - alemães e italianos, principalmente - e aqueles dirigidos ao leitor mais segmentado, seja o intelectual ou a jovem senhora de família, além dos jornais operários, nada mais fazem que enfatizar essa nova perspectiva. É para e com o receptor que os novos editores e proprietários de publicações se dirigem e se preocupam (HOHLFELDT; RAUSCH, 2006, p. 5).

No que tange à imprensa, nas áreas de imigração alemã no estado, muitos desses editores/intelectuais que se estabeleceram no Brasil e especialmente no Rio Grande do Sul, a partir de meados do século XIX, ficaram conhecidos como a geração de 48 , pois muitos foram oriundos da fracassada tentativa de unificação alemã no citado ano (incluso, o já referido Karl Von Koseritz).

${ }^{14}$ Sobre o estudo da influência partidária nos jornais no Rio Grande do Sul, sugere-se a leitura de: RÜDIGER (1993); Hohlfeldt e Rausch (2006).

${ }^{15}$ Existia uma diversidade de jornais no interior, Hohlfeldt e Rausch (2006) destacam que mais de 60 municípios do Rio Grande do Sul, a partir de 1850, já possuíam jornais. Isso representava, praticamente, um veículo de comunicação por município no Rio Grande do Sul no século XIX. Mas, de um modo geral, eles seguiam a tendência político-partidária dos influentes jornais de nível estadual. 
Foi através do uso de jornais e do kalender ${ }^{16}$ que se buscou cativar/cooptar os teuto-brasileiros para a participação nas questões políticas, atingindo principalmente a população dos núcleos rurais (maior parte da população de imigrantes alemães vivia em núcleos interioranos rurais), em cujos jornais se via uma apologia à necessidade do imigrante se engajar na cidadania plena brasileira e ter direito à participação política.

Os jornais também propunham a necessidade de se constituir uma identidade genuinamente teuto-brasileira, onde se frisava a amálgama de cidadania brasileira (por isso a luta pela participação na política): a pátria é o Brasil, mas a luta é para a preservação da nacionalidade alemã. Koseritz exemplifica esse pensamento através do seguinte pronunciamento:

Entre nós, no Rio Grande, a bandeira brasileira não falta nunca ao lado da alemã, pois a grande maioria dos homens de língua alemã de lá já é nascida no Brasil e uma grande porcentagem dos imigrantes é naturalizada. O centro de nossos interesses está no Brasil, nós devemos participar da vida pública do país, no qual não vivemos temporariamente, mas onde nos estabelecemos e fundamos as nossas famílias, que ao Brasil dão o nome de pátria. [...] Mas nem por isto deixamos de guardar no coração um fiel amor pela velha terra, e sempre a ajudamos, quando ela atravessa horas penosas. A língua e os costumes alemães, o amor alemão ao trabalho e a fidelidade alemã são praticados por nós como talvez por ninguém mais no exterior, e nós mantemos os laços espirituais com a Alemanha tão firmemente quanto aderimos decididamente ao Brasil pelos laços políticos (KOSERITZ, 1980 apud ARAUJO, 2012, p. 82).

Nesse caso da nacionalidade alemã pode se entender, a partir do discurso de Koseritz, que estão retomados os preceitos básicos inspirados no pensamento de Herder e Fichte, que seriam a percepção do Volkstum, a etnicidade, e o Deutschtum, a preservação da cultura, da língua, do passado comum, sendo essa amálgama a questão máxima do nacionalismo teuto-brasileiro.

Os meios de comunicação, então, serviram como base não só de propagação do nacionalismo teuto-brasileiro, mas também como um instrumento de cooptação político/filosófica por parte dos jornais, os quais, apesar das divergências já exemplificadas, apresentavam aspectos comuns:

É possível verificar alguns pontos de convergência entre as diferentes lideranças citadas. Um deles é a atividade intelectual na redação ou edição de jornais voltados ao público de língua alemã. A partir deles, aqueles conseguiam divulgar suas ideias, fazer ouvir seus discursos, influenciar leitores, angariar aliados e opositores. Demonstravam um intenso empenho pela demarcação dos limites do grupo teuto ou teuto-brasileiro, pela caracterização desta identidade, pela definição dos aspectos a serem preservados e dos aspectos a serem assimilados (SILVA, 2005, p. 306).

${ }_{16}[. .$.$] O princípio das diversas lições, ou seja, de tudo um pouco para alcançar os diferentes$ tipos de leitores e suas preferências de leitura, repertório esse variável, conforme a época de circulação dos almanaques, que inclui, basicamente, as seguintes formas: contos, contos de fada, lendas, novelas, poemas, aforismos, epigramas, anedotas: artigos de cunho histórico, cultural e geográfico, principalmente os aspectos regionais; relatos sobre as descobertas, sobre os progressos na técnica e na ciência, sobre artes e literatura; biografias de vultos significativos do passado e do presente; retrospectivas e prospectivas no âmbito da política internacional; exposições de cunho religioso (GRÜZTZMANN, 2004, p. 23). 
Destacam-se como jornais de grande relevância, associados aos três grupos político-filosóficos, os jornais Koseritz Deutsche Zeitung e Koseritz Deutschen Volkskalender für Brasilien (SEYFERTH, 1993), auspiciados pelos liberais liderados por Koseritz; o almanaque Kalender für die Deutschen in Brasilien e o jornal Deutsche Post (SILVA, 2005), articulado pelo pastor luterano Rotermund; e o Deutsches Volksblatt, jornal que era editado desde 1871 pelos jesuítas (GERTZ, 2010). Muitos desses jornais ou almanaques possuíam uma alta tiragem, com números superiores a dez mil exemplares, o que, para padrões da época, representava um forte instrumento de divulgação e doutrinação.

Não é propósito deste artigo aprofundar o mérito de cada jornal ou almanaque, e sim demonstrar o modo como eles serviram como instrumento para a propagação da nacionalidade teuto-brasileira, pois constata-se em praticamente todos esses periódicos a preocupação com a perda da identidade nacional alemã, num processo de aculturação por parte dos imigrantes e seus descendentes. Era necessário preservar, acima de tudo, o Volkstum e o Deutschtum. Curiosamente, Fichte (2010) também possuía essa preocupação, mas num cenário totalmente diferenciado, pois, no início do século XIX, era o território alemão que estava sendo invadido por estrangeiros (no caso, franceses). Agora a situação seria o oposto, quem "invadiu" o território estrangeiro foram os alemães, mas preservar a cultura alemã era considerado imprescindível, a ponto de Koseritz pregar a formação de rincões culturais alemães para evitar principalmente a perda da essência da cultura alemã: a sua língua.

\section{Considerações finais}

A partir da análise das propostas filosóficas e nacionalistas de Herder (1959) e Fichte (2010) - com o germanismo, em suas múltiplas faces, realizado no Brasil, no decorrer do século XIX - pode-se constatar que muitos aspectos apresentados pelos filósofos germânicos se constituíram em práticas políticas e sociais por parte dos descendentes alemães no Brasil.

Aspectos como a valorização da língua, da cultura e das tradições/romantismo (antepassados) estão presentes em praticamente todos (se não todos) os intelectuais germanistas situados no Brasil, no século XIX, evidenciados através do Deutschtum. Além da questão da etnicidade e da crença na superioridade da etnia, a destacada importância da preservação da identidade alemã estabelecidas pela concepção do Volkstum, são marcas indeléveis e impregnadas pelos germanistas.

Esses aspectos foram intensamente frisados pelos intelectuais de origem alemã, conhecidos como germanistas, os quais tiveram em Koseritz seu expoente máximo apesar de existirem várias ramificações filosóficas, inclusive rivais - sendo o nacionalismo teuto-brasileiro embasado na luta pela cidadania plena e propagado através de jornais e almanaques.

Observa-se que essa busca identitária conseguiu sobrepor-se às diferenças religiosas e regionais estabelecidas nas colônias no Rio Grande do Sul e no Brasil, contendas muitas vezes advinda das próprias origens distintas dos alemães que migraram de várias regiões dos reinos germânicos. Além de moldar um teuto-sul-rio-grandenses sob um modelo de perfeição, essa questão ainda permeia no imaginário popular. 
A base fundamental do embasamento axiomático do nacionalismo teuto-brasileiro foi a separação entre nação e pátria. Essa é uma das mais fortes comprovações das influências de Herder e Fichte, que apesar das diferenças em suas concepções filosóficas, acabaram por vincular os laços de uma nação ao pertencimento étnico e não pátrio. Ou seja, poder-se-ia ser alemão em qualquer parte do mundo, bastava seguir sua língua, suas tradições e possuir o sangue germânico circulando nas veias.

Verifica-se, assim, a importância da língua e da conservação das tradições para a continuidade das identidades. Esses elementos preservados são traços identitários que quando se mantêm, mesmo que modificados, são uma forma de preservação ou continuidade identitária, muitas vezes ainda presente e perceptível na sociedade atual.

\section{Referências}

ARAUJO, Rodrigo Cardoso Soares de. Laços e traços de identidade numa leitura de Karl von Koseritz. Rev. Hist. UEG - Goiânia, v. 1, n. 1, p. 65-85, jan./jun. 2012.

DREHER, Martin (Org.). Hermann Gottlieb Dohms: textos escolhidos. Porto Alegre: Edipucrs, 2001.

. O Fenômeno Imigratório Alemão para o Brasil. Estudos Leopoldenses, v. 31, n. 142, p. 59-82, maio/jun., 1995.

FICHTE, Johann Gottlieb. Discursos à nação alemã. Lisboa: Círculo de Leitores - Temas e Debates, 2010.

GERTZ, René. A República no Rio Grande do Sul: política, etnia e religião. História Unisinos, ano 14, v. 1, p. 38-48, jan./abr. 2010.

(Org). Karl Von Koseritz: seleção de textos. Porto Alegre: Edipucrs, 1999.

GRÜZTZMANN, Imgart: O almanaque (Kalender) na imigração alemã na Argentina, no Brasil e no Chile. In: DREHER, Martin; RAMBO, Arthur Blásio; TRAMONTINI, Marcos (Orgs). Imigração \& Imprensa. Porto Alegre: EST; São Leopoldo: Instituto Histórico de São Leopoldo, 2004.

. Intelectuais de fala alemã no Brasil do século XIX: o caso Karl von Koseritz (1830-1890). História Unisinos, ano 11, v. 1, p. 123-133, jan./abr., 2007.

HERDER, Johann Gottfried Von. Ideas para una filosofía de la historia de la humanidad. Buenos Aires: Editorial Losada, 1959.

HOHLFELDT, Antônio; RAUSCH, Fábio Flores. A Imprensa sul-rio-grandense entre 1870 e 1937: discussão sobre critérios para uma periodização. 2006. Disponível em:

<http://www.essenciaeditora.com.br/antoniohohlfeldt/fl_adm/uploads/ar/a-imprensasul-rio-grandens-entre-1870-e-1937.pdf>. Acesso em: 10 ago. 2014.

OLIVEIRA, Ryan de Sousa. Colonização alemã e cidadania: a participação política dos teuto-brasileiros no Rio Grande do Sul (século XIX). Textos de História, v. 16, n. 2, 2008. 
PESAVENTO, Sandra Jatahy. História do Rio Grande do Sul. 8. ed. Porto Alegre: Mercado Aberto, 1997

RÜDIGER, Francisco. Tendências do jornalismo. Porto Alegre: UFRGS, 1993.

SEYFERTH, Giralda. Identidade étnica, assimilação e cidadania a imigração alemã e o Estado brasileiro. Trabalho apresentado no XVII Encontro Anual da ANPOCS. Caxambu, 22-25 de outubro de 1993.

SILVA, Haike Roselane Kleber da. A identidade teuto-brasileira pensada pelo intelectual Aloys Friederichs. Anos 90, Porto Alegre, v. 12, n. 21/22, p. 295-330, jan./dez. 2005. 